\title{
Contextual Effect of Preschool on the Development of Children Under Five in Surabaya, East Java
}

\author{
Ajeng Ayu Titah Pujangkara'), Harsono Salimo²), Eti Poncorini Pamungkasari3) \\ 1)Masters Program in Public Health, Universitas Sebelas Maret \\ 2)Department of Pediatrics, Dr. Moewardi Hospital, Surakarta \\ 3)Faculty of Medicine, Universitas Sebelas Maret
}

\section{ABSTRACT}

Background: The development of children in the first 1000 days is influential in the long term. Therefore, it requires education at an early age to achieve optimal development. This study aimed to analyze the contextual effect of early childhood education on the development of children under five at Surabaya.

Subjects and Method: This was a crosssectional study conducted 25 preschools in Wonokromo, Surabaya, East Java, Indonesia. The study population was all children aged 2-5 years. A sample of 200 children aged 2-5 years from 25 preschools was selected randomly. The dependent variable was child development. The independent variables were the history of infectious disease, exclusive breastfeeding, number of children, maternal education, maternal occupation, family income, nutritional status, mother tongue, birth weight, and preschool level. The data were analyzed using a multilevel multiple logistic regression run on STATA 13.

Results: Child development disorders in children aged 2-5 years increased with history of infectious disease $(\mathrm{b}=1.35 ; 95 \% \mathrm{CI}=0.39$ to 2.31 ; $\mathrm{p}=0.005)$, poor nutrition status $(\mathrm{b}=1.07 ; 95 \%$ $\mathrm{CI}=0.06$ to $2.08 ; \mathrm{p}=0.036$ ), low family income $(b=1.89 ; 95 \% \mathrm{CI}=0.91$ to $2.86 ; \mathrm{p}<0.001)$, mothers who work outside $(b=1.06$; $95 \% \mathrm{CI}=$ 0.19 to $1.94 ; \mathrm{p}=0.017)$, low maternal education $(b=1.21 ; 95 \% \mathrm{CI}=0.20$ to $2.22 ; \mathrm{p}=0.018)$, and non-exclusive breastfeeding $(\mathrm{b}=1.48 ; 95 \% \mathrm{CI}=$ 0.52 to $2.44 ; p=0.002$ ). Preschools had weak contextual effect on the development of children under five with $\mathrm{ICC}=9.4 \%$.

Conclusion: Child development disorders in children aged 2-5 years increases with history of infectious disease, poor nutrition status, low family income, mothers who work outside, low maternal education, and non-exclusive breastfeeding. Preschools have weak contextual effect on the development of children under five.

Keywords: child development, children under five, preschool

\section{Correspondence:}

Ajeng Ayu Titah Pujangkara. Masters Program in Public Health, Universitas Sebelas Maret. Jl. Ir. Sutami 36A, Surakarta 57126, Central Java. Email: ajengayutitah@gmail.com. Mobile: +628116119511.

Cite this as:

Pujangkara AAT, Salimo H, Pamungkasari EP (2020). Contextual Effect of Preschool on Children under Five's Development in Surabaya, East Java. J Matern Child Health. 05(03): 331-345. https://doi.org/10.26911/thejmch.2020.05.03.12.

(c) (7) (-) Journal of Maternal and Child Health is licensed under a Creative Commons Attribution-Non Commercial-Share Alike 4.o International License.

\section{BACKGROUND}

In 2030, the government is committed to achieving the Sustainable Development Goals's (SDG) targets specifically concerning children's development. According to the Indonesian Children's Profile (2018), a variety of strategies at the national and regional levels have been developed to achieve the specified targets. Targets to be achieved include eliminating child poverty; no more children are malnourished and die of treatable diseases; creating a child-friendly environment; meet the needs of children's education, especially education at an early age; and other targets. 
The first five years of life is a time that is very sensitive to the environment and this period lasts very short and cannot be repeated anymore, so the toddler period is called a "golden period", "window of opportunity", and "critical period".

The Statistics Indonesia (BPS) in the Profile of Indonesian Children (2018), projects that 30.5 percent or 79.6 million of Indonesia's population in 2017 are children aged 0-17 years, meaning that almost one in three Indonesians are children.

Indonesia Health Profile 2018 stated that only $67.48 \%$ of children under five in Indonesia are weighed every month and as many as $80.92 \%$ of children under five are declared thin and get extra food. A total of 1,496 children aged 0-59 months were never weighed in the last 12 months in the province of East Java (Health Office of East Java, 2018). These things indicate that there is still a lack of awareness of parents in monitoring children's growth and development.

The Department of Health in collaboration with the Indonesian Pediatric Society (IDAI) has compiled various instruments for stimulation, detection, and early intervention of growth and development for children aged three months to 72 months, namely the development pre-screening questionnaire (KPSP).

This instrument is intended not only for health workers in the Public health center and its staff (doctors, midwives, nurses, nutritionists, public health counselors, and other health workers who care for children) but also for other sector staff in carrying out the task of stimulating and detecting premature deviation of child growth and development. Caregivers or Early Childhood Education (PAUD) teachers are one of the partners of health workers in conducting stimulation and early detection of deviations of child development (Wati, 2017). One of the interventions is the Predevelopment pre- screening questionnaire (KPSP) which can be used to see a child's development.

Factors that affect development are seen from the social environment, parenting, language use, and early childhood education (Wijayanti et al., 2018). Another study also mentions one of the factors that influence development, which is an infection or disease, which is mentioned in the study of Pinkerton (2016). the child. There is an effect between the history of breastfeeding and weaning food on the development of children aged 12-24 months (Suryanaet al., 2018). Also, external factors can affect the development of toddlers family income (Lolita et al., 2019), number of children (Blumenfeld et al., 2018), birth weight (Kusumasari et al., 2016), stimulation (Ulfah et al. , 2018), nutritional status of under-fives lacking influence on growth and if it occurs continuously will have an impact on the development of under-fives (Indriyani et al., 2018).

According to the Minister of Health Regulation of the Republic of Indonesia number 66 of 2014 concerning monitoring of growth, development and developmental disorders of children in article 4 paragraph 1 which reads the monitoring of growth, development and developmental disorders of children being carried out in primary health care facilities and kindergarten (Ministry of Health, 2014). According to the Ministry of Education and Culture reference data in East Java alone, there are 45,414 preschool and 2,869 in Surabaya.

Based on the background above, the causes of developmental disorders have many risks, therefore it is necessary to conduct a study at the Individual level and level II, namely analyzing the contextual effect of preschool (detection of development with KPSP and WHO z-score) in the City of Surabaya, East Java. 


\section{SUBJECTS AND METHOD}

\section{Study Design}

This study was a cross-sectional study that was done in Wonokromo District, Surabaya, East Java, Indonesia in January to February 2020.

\section{Population and Sample}

The source population in this study was children under five aged over 24 months to 60 months who were from 25 preschools in Wonokromo district, Surabaya. The total sample of 200 study subjects consisted of 8 children under five taken from 25 preschools. The sampling was done using Simple Random Sampling technique.

\section{Study Variables}

The dependent variable was children underfive's development. The independent variables were the history of infectious disease, number of children, nutritional status, exclusive breastfeeding, maternal education, maternal occupation, family income, contextual preschool.

\section{Operational Definition of Variables} History of infectious disease is an infectious disease such as diarrhea (liquid bowel that was experienced by children under five with (frequency) or more in one day), ARI (cough, difficulty breathing) suffered by toddlers in the past 6 months. Categorical data scales were changed to dichotomies when analyzing data.

Number of children was the number of children owned in one family. Continuous data scales were converted into dichotomies during data analysis. Code o: ideal $<3$ children, 1 : ideal number $\geq 3$ children.

Maternal education was the status of formal education (elementary, junior high, high school, college) that was taken by mothers based on the last diploma obtained. Categorical data scale. Code o: further or higher education (high school, university), 1: basic education (elementary and junior high school or equivalent).
Maternal occupation was the work of mothers inside or outside the house, both formal and informal, which was done in the amount of time spent during the day. Categorical data scale. Code o: Work inside the home, 1: work outside the home.

Family income was the amount of family income received in one month as a source of economic family for the last 6 months. Revenues could be measured by Regency or City Minimum Wages. Continuous data scales were changed to a dichotomy during data analysis, code $\mathrm{o}=\geq \mathrm{UMK}=\mathrm{Rp}$ 4,200,000, 1 : $<\mathrm{UMK}=\mathrm{Rp} 4,200,000$.

History of exclusive breastfeeding was the period of a baby given exclusive breastfeeding for 6 full months without any food and drinks other than breast milk. Continuous data scales were converted to a dichotomy when analyzing data. Code 0 : exclusive breastfeeding for 6 full months. 1: No exclusive breastfeeding for 6 full months.

Nutritional status was the ratio between body weight (Kgs) and age (month) of children under five according to Kepmenkes No. 1995 / MENKES / SK / XII / 2010 and by looking at the WHO growth chart z-score table (2005). Nutritional status studied by Weight for Age. Continuous data scales were converted to a dichotomy when analyzing data. o: ideal nutritional status (sufficient) (2.o SD to 2.o SD), 1: underweight nutritional status (<-2.0 SD).

Contextual integrated healthcare center (Posyandu) was preschool level in the form of characteristics that were differentiated based on services provided by facilities and infrastructure, teaching methods and curriculum provided. Categorical data scale. Code o: Child Care Park (TPA), 1: Study Group, 2: Kindergarten, 3: Kindergarten Unit Similar.

\section{Study Instruments}

The study instrument used for data collection was a questionnaire that was tested for vali- 
dity and reliability. The questionnaire was used to measure the history of infectious disease, number of children, nutritional status, maternal education, maternal occupation, family income, history of exclusive breastfeeding, and types of preschool.

\section{Data Analysis}

Univariate analysis was used to see the frequency distribution and percentage characteristics of subjects of the study. Bivariate analysis was conducted to examine the correlations between independent variables on child development using Chi-square. Multivariate analysis used logistic regression analysis through a multilevel approach with the Stata 13 program to find out the contextual effect of preschool on children's development.

\section{Research Ethics}

Ethical clearance in this study was obtained from the Health Research Ethics Commission of Moewardi Hospital Surakarta City with the number 1,287 / XII / HREC / 2019 published on December 3, 2019.

\section{RESULTS}

\section{Sample Characteristics}

Characteristics that were studied included the history of infectious disease, nutritional status, family income, maternal education, exclusive breastfeeding, maternal occupation, children's development, birth weight, mother tongue and Early Childhood Education or preschool. These characteristics could be shown in Table 1 and Table 2.

Table 1. The Characteristics of Study Subjects (Continuous Data)

\begin{tabular}{lccccc}
\hline \multicolumn{1}{c}{ Characteristic } & N & Mean & SD & Min. & Max. \\
\hline Income (Rupiahs) & 200 & $4,830,500$ & $2,311,109$ & $1,000,000$ & $15,000,000$ \\
Number of children & 200 & 1.86 & 0.85 & 1 & 4 \\
Development & 200 & 8.72 & 0.90 & 7 & 10 \\
Nutritional status (WAZ) & 200 & -1.2 & 1.43 & -3 & 3 \\
Birth weight (gram) & 200 & $3,145.45$ & 441.36 & 2,300 & 4,500 \\
\hline
\end{tabular}

Table 2. Characteristics of Study Subjects (Dichotomous Data)

\begin{tabular}{lcc}
\hline Characteristic & Frequency (n) & Percent (\%) \\
\hline History of infectious disease & & \\
Never & 137 & 68.5 \\
Ever & 63 & 31.5 \\
Nutritional status & 151 & 75.5 \\
Good nutrition & 49 & 24.5 \\
Malnutrition & & 67.0 \\
Family Income & 134 & 33.0 \\
ZRegional Minimum Wage & 66 & 78.0 \\
< Regional Minimum Wage & & 22.0 \\
Maternal education & 156 & \\
$\geq$ Senior High School & 44 & 59.0 \\
< Senior High School & & 41.0 \\
Exclusive breastfeeding & 118 & \\
Yes & 82 & 53.0 \\
No & & 47.0 \\
Maternal occupation & 106 & 81.5 \\
Work at home & 94 & 18.5 \\
Work outside at home & & \\
Number of children & 163 & \\
<3 children & 37 & \\
$\geq 3$ children & & \\
\hline
\end{tabular}




\section{The result of bivariate analysis}

The analytical test used in the bivariate analysis was the chi-square test. Bivariate analysis based on the results of this study can be seen in Table 3. In table 3 shows that the history of infectious disease affected the child's development. Children who had had an infection are more likely to be 3.59 more likely to experience developmental disorders $(\mathrm{OR}=3.59 ; \mathrm{p}=0.005)$.

Children's nutritional status affected the development of a child. Children with malnutrition were 2.94 times more likely to experience developmental disorders $(\mathrm{OR}=$ 2.94; $\mathrm{p}=0.026$ ).

Family income affected the child's development. Children who live with an income family below the regional minimum wage were 6.27 times as likely to have developmental disorders $(\mathrm{OR}=6.27$; $\mathrm{p}<\mathrm{0.001})$.
Maternal education affected the development of children. Children from mothers with low education level were 3.14 times more likely to experience developmental disorders $(\mathrm{OR}=3.14 ; \mathrm{p}=0.020)$.

The history of exclusive breastfeeding affected the child's development. Children with a history of no exclusive breastfeeding were 4.32 times more likely to have developmental disorders ( $\mathrm{OR}=4.32 ; \mathrm{p}=0.002)$.

Maternal occupation affected the development of children. Children with mothers who work outside the home were 2.64 times more likely to experience developmental disorders $(\mathrm{OR}=2.6 ; \mathrm{p}=0.019)$. The number of children in the family affected the development of the child. The number of children who were not ideal in a family is 3.24 times more likely to experience developmental disorders $(\mathrm{OR}=3.24 ; \mathrm{p}=0.029)$.

Table 3. Bivariate Analysis on the Determinants of Child Development

\begin{tabular}{|c|c|c|c|c|c|c|}
\hline \multirow{3}{*}{ Independent Variable } & \multicolumn{4}{|c|}{ Child Development } & \multirow{3}{*}{$\mathbf{O R}$} & \multirow{3}{*}{$\mathbf{p}$} \\
\hline & \multicolumn{2}{|c|}{ Good } & \multicolumn{2}{|c|}{ Poor } & & \\
\hline & $\mathbf{N}$ & $\%$ & $\mathbf{N}$ & $\%$ & & \\
\hline \multicolumn{7}{|c|}{ History of Infectious Disease } \\
\hline Never & 97 & 70.8 & 40 & 29.2 & \multirow{2}{*}{$3 \cdot 59$} & \multirow[t]{2}{*}{0.005} \\
\hline Ever & 20 & 31.7 & 43 & 68.2 & & \\
\hline \multicolumn{7}{|l|}{ Nutritional Status } \\
\hline Good Nutritional Status & 102 & 67.5 & 49 & 32.4 & \multirow[t]{2}{*}{2.94} & \multirow[t]{2}{*}{0.026} \\
\hline Malnutrition & 15 & 30.6 & 34 & 69.4 & & \\
\hline \multicolumn{7}{|l|}{ Family Income } \\
\hline$\geq$ Regional Minimum Wage & 96 & 71.6 & 38 & 28.4 & \multirow[t]{2}{*}{6.27} & \multirow[t]{2}{*}{$<0.001$} \\
\hline$<$ Regional Minimum Wage & 21 & 31.8 & 45 & 68.2 & & \\
\hline \multicolumn{7}{|l|}{ Maternal Education } \\
\hline$\geq$ Senior high school & 104 & 66.7 & 52 & $33 \cdot 3$ & \multirow[t]{3}{*}{3.14} & \multirow[t]{2}{*}{0.020} \\
\hline$<$ Senior high school & 13 & 29.5 & 31 & 70.4 & & \\
\hline \multicolumn{6}{|l|}{ Exclusive breastfeeding } & \\
\hline Yes & 88 & 74.8 & 30 & 25.4 & \multirow[t]{3}{*}{4.32} & \multirow[t]{2}{*}{0.002} \\
\hline No & 29 & $35 \cdot 3$ & 53 & 64.6 & & \\
\hline \multicolumn{6}{|l|}{ Maternal Occupation } & \\
\hline Work at home & 69 & 65.1 & 37 & 34.9 & \multirow[t]{3}{*}{2.64} & \multirow[t]{3}{*}{0.019} \\
\hline Work from outside the home & 48 & 51 & 46 & 48.9 & & \\
\hline \multicolumn{5}{|l|}{ Number of Children } & & \\
\hline$<3$ children & 103 & 63.2 & 60 & 36.8 & \multirow[t]{2}{*}{3.24} & \multirow[t]{2}{*}{0.029} \\
\hline$\geq 3$ children & 14 & 37.8 & 23 & 62.2 & & \\
\hline
\end{tabular}


Pujangkara et al./ Contextual Effect of Preschool on Children under Five's

Table 4. Multilevel Multiple Logistic Regression Analysis of Children's Development

\begin{tabular}{|c|c|c|c|c|}
\hline \multirow{2}{*}{ Independent variable } & \multirow{2}{*}{$\begin{array}{c}\text { Regression } \\
\text { coefficient (b) }\end{array}$} & \multicolumn{2}{|c|}{$95 \% \mathrm{CI}$} & \multirow{2}{*}{$\mathbf{p}$} \\
\hline & & Lower limit & Upper limit & \\
\hline \multicolumn{5}{|l|}{ Fixed effect } \\
\hline History of infectious disease (yes) & 1.35 & 0.39 & 2.31 & 0.005 \\
\hline Nutritional Status (malnutrition) & 1.07 & 0.06 & 2.08 & 0.036 \\
\hline Income (low) & 1.89 & 0.91 & 2.86 & $<0.001$ \\
\hline Maternal occupation (outside) & 1.06 & 0.19 & 1.94 & 0.017 \\
\hline Maternal education (low) & 1.21 & 0.20 & 2.22 & 0.018 \\
\hline Exclusive breastfeeding (no) & 1.48 & 0.52 & 2.44 & 0.002 \\
\hline Number of children ( $\geq 3$ children) & 1.21 & 0.10 & 2.32 & 0.032 \\
\hline Constant & -3.18 & & & \\
\hline \multicolumn{5}{|l|}{ Random Effect } \\
\hline Var (Constant) & 0.342 & & & \\
\hline $\mathrm{N}$ observation $=200$ & & & & \\
\hline $\mathrm{N}$ group $=25$ & $\operatorname{Min}=8, \max =8$ & & & \\
\hline Log Likelihood $=-85.74$ & $\mathrm{p}<0.001$ & & & \\
\hline Group average $=8$ & ICC $=9.4 \%$ & & & \\
\hline
\end{tabular}

\section{The result of multilevel analysis}

The multivariate analysis explained the effect of more than one independent variable (history of infectious disease, nutritional status, maternal education, maternal occupation, exclusive breastfeeding, family income, mother tongue, birth weight, and number of children) with the dependent variable namely the development of children. The following are results of multivariate analysis of children's development using multiple logistic regression with a multilevel approach that can be seen on Table 4.

\section{a. The Effect of History Infectious Di-} sease on Children's Development

Table 4 shows the effect of the history of infectious disease on the development of children under five. Children under five who had had a history of infectious disease had a possibility (log odd) to experience developmental disorders 1.35 units higher than children under five who had never had a history of infectious disease $(b=1.35 ; 95 \% \mathrm{CI}=0.39$ to 2.31; $\mathrm{p}=0.005$ ).

\section{b. The Effect of Nutritional Status on Children's Development}

There was an effect of nutritional status on the development of children under five.
Children under five with malnutrition status had the possibility (logodd) to experience developmental disorders of 1.07 units higher than those with good nutritional status $(b=$ 1.07; 95\% $\mathrm{CI}=0.06$ to $2.08 ; \mathrm{p}=0.036$ ).

c. The Effects of Family Income on Children's Development

There was an effect of family income on the development of children under five. Children under five with low family income had the possibility (log odd) to experience developmental disorders 1.89 units greater than children with high income family $(b=1.89$; 95\% CI= 0.91 to 2.86 ; $p<0.001)$.

\section{d. The Effect of Maternal Education on Children's Development}

There was an effect of maternal education on the development of children under five. Children under five from mothers with low education levels had the possibility (log odd) to experience developmental disorders 1.21 units higher than those who had mothers with high education $(b=1.21 ; 95 \% \mathrm{CI}=0.20$ to $2.22 ; \mathrm{p}=0.018$ ).

\section{e. The Effect of History of Exclusive Breastfeeding on Children}

There was an effect of exclusive breastfeeding on the development of children under five. 
Children under five with incomplete exclusive breastfeeding had a possibility (log odd) to experience developmental disorders 1.48 units higher than those with exclusive breastfeeding $(b=1.48 ; 95 \% \mathrm{CI}=0.52$ to $2.44 ; \mathrm{p}=$ 0.002).

\section{f. The Effect of Maternal Occupation on Children's Development}

There was an effect of maternal occupation on the development of children under five. Children under five who live with mothers who work outside the home had the possibility (log odd) to experience developmental disorders 1.06 units greater than mothers who work at home $(b=1.06 ; 95 \% \mathrm{CI}=0.19$ to 1.94 ; $\mathrm{p}=0.017$ ).

\section{g. The Effect of Number of Children on Children's Development}

There was an effect of the number of children in the family on the development of children under five. Children under five who live in families with less than the ideal number of children had a (log odd) chance of experiencing developmental disorders 1.21 units greater than children under five living in families with the ideal number of children $(b=1.21$; 95\% CI= 0.10 to 2.32; $\mathrm{p}=0.032$ ).

\section{h. The Contextual Effect of Preschool on Children's Development}

There was a contextual effect of preschool seen in the value of the ICC. The value of the ICC in this study amounting to $9.4 \%$ indicating that in accordance with thumb rule 810\%. Early childhood development of each preschool was different so it was an important factor.

\section{DISCUSSION \\ 1. The Effect of History of Infectious Disease on Children's Development}

This study shows the results that there is an effect of a history of infectious disease on children's development. The results of the analysis note that children under five who have had a history of infectious disease can cause developmental disorders.

A study conducted by Yadika (2019), showed that a history of infectious disease can cause a child to become stunted and this disrupts motor, cognitive and verbal development. In the stunting condition, disruption in the process of brain neuron maturation and changes in brain structure and function can occur that can cause permanent damage to cognitive development. This condition causes the child's ability to think and learn to be disrupted and ultimately reduces the level of attendance and learning achievement.

According to Mokomane et al. (2018), infectious diseases, such as diarrhea can disrupt children's development. The diarrheal disease can cause not only short-term death but also for impaired cognitive development, lack of schooling, lack of economic productivity in adulthood, and can lead to a tendency to develop metabolic diseases in adulthood and reduce childbirth weight (Khalil et al., 2016).

In infectious diseases, there is an inflammatory process in the body, this process will be able to affect a toddler in its development. It was mentioned in a study conducted by Jensen et al. (2019) that inflammation can affect a child's development through different pathways including the direct effect of inflammation on growth and nerve function, disease behavior in children which might delay learning, and interactions with other biological processes in the body.

\section{The Effects of Nutritional Status on Children's Development}

The results of this study indicate that there is an effect between nutritional status on children's development and is statistically significant. The results of the analysis note that toddlers with malnutrition status are more at risk of developing developmental disorders. Malnutrition can also have a direct effect on the central nervous system of children. This 
complex correlation makes it difficult to separate the right mechanism from the relationship between deficits in growth and poor mental development (Onis, 2017).

Another study also shows that nutritional status affects early childhood development. Children with good nutritional status have appropriate development compared to children with malnutrition $(\mathrm{p}=0.008)$. There is a positive effect between nutritional status and early childhood development. Good nutritional status improves early childhood development (Hardillaet al., 2020).

Food intake affects the development and function of the brain in all age groups, starting from pregnancy in terms of cognitive processes, moods, and brain performance. Therefore, nutritional deficiencies can cause a large number of clinical symptoms that depend on age, which affects the functioning of the central nervous system (Lambregts, 2017).

Another study conducted by Cyr (2016), also mentioned that nutritional deficiencies in early life can have permanent effects into adulthood. Nutritional deficiencies early in life affect the number of cells produced in the brain and body, while childhood deficiencies affect the size and complexity of cells, determining how productive and functional they are in the body. The effects of nutritional deficiencies can have severe and permanent effects on children if the deficiency is experienced very early in life and for a long period. The younger a child is, and the longer they lack essential nutrients, the more likely they are to experience severe, lasting cognitive, emotional and physical effects.

Micronutrient deficiency can cause dramatic disruptions in a child's development. Nutrition is calculated as an environmental factor. Iron and iodine deficiency both affect cognitive development. A study shows how malnutrition can interfere with the develop- ment of neurons in the human brain (Krämer, 2017).

\section{The Effects of Family Income on Children's Development}

The results of this study indicate that there is an effect of family income on children's development and is statistically significant. The results of the analysis note that children under five who live in families with low income are more at risk of developmental disorders.

Low family income is synonymous with poverty, which is one factor of developmental disorders in children. Poverty, socio-cultural factors, and psychosocial and biological risk factors all work together to affect child development and long-term adult productivity (Fernald, 2017).

This is following a study conducted by Black et al. (2017) which stated that difficulties of a child's early life can affect life development, especially when there are many difficulties such as poverty, malnutrition, high crime community, and low-quality resources. In addition to differences in vocabulary, the parental income also plays a role in facilities that play a role in the child's developmental period. One of these facilities can be in the form of the ability to check progress in a health facility and intervene as early as possible if there is a delay (Urke, 2018).

Economic status affects children's language and speech development. The analysis used stated that high economic status will make it easier for children to get access to learning because of the availability of funds owned by parents. Access to toddler learning can be both formal and informal. Formal means involving toddlers in early childhood (PAUD) and informal playgrounds can be done at home by providing children with play facilities that can hone their children's language and speech development abilities (Pace et al., 2017). 
Studies conducted by the Institute of Nutrition of Central America and Panama (INCAP), have monitored growth and development over the past 50 years showing that environmental factors related to poverty have a greater impact on a child's growth and functional development than genetic factors (Piper et al., 2017).

\section{The Effects of Maternal Education on Children's Development}

The results of this study indicate that there is an effect between maternal education on child development and is statistically significant. The results of the analysis note that toddlers with mothers with low education levels are more at risk of developing developmental disorders.

Previous study conducted by Jeong et al. (2017) state that more highly educated mothers have shown greater knowledge about child development, use more complex language and vocabulary with their children, invest more in the health of their children, have more books at home, and also have higher educational expectations for their children.

Regarding nurturing a child's development, mothers with higher education can create a more friendly and healthier home environment for child development, such as having more roles in economic matters, better parenting behavior, greater information processing capacity, and efficiency higher investment in human development (Cui et al., 2019).

Mothers play a more important role in the child's development process. Therefore, low maternal education will affect the health of children at an early age which can result in developmental disorders (Keats, 2018).

A study conducted by Farooq et al. (2019) showed that the education of elementary and middle/high school mothers was significantly recorded as a more protective measure to avoid toddlers who avoid poor growth and development compared to mothers without education. The impact of good maternal education will affect a child's health outcomes in the long run. Thus, this study estimates that the impact of maternal school can affect a child's chronic malnutrition (Slemming, 2017; Rachmi, 2016).

\section{The Effect of Maternal Occupation on Children's Development}

The results of this study indicate that there is an effect between maternal occupation on children's development and is statistically significant. The results of the analysis note that toddlers with mothers who work outside the home are more at risk of developing developmental disorders.

Other studies have also shown the same results, namely the possibility that stress or fatigue associated with work can negatively affect the interaction of mothers with children. It can be said, the work of mothers outside the home weakens family bonding, which includes the frequency of interaction and the strength of the bond developed between parents and children. The participation of maternal labor outside the home is considered to contribute to reducing the time spent with children, limiting the role of the family in the socialization process and therefore potentially leading to behavioral problems or negative outcomes during childhood development (Vikram et al., 2018).

The same thing was conveyed in previous studies that mothers can work but must pay attention to the time when leaving the child. The ideal time to work is 8 hours/day. This is because mothers need time to do bonding or quality time with their children to obtain optimal development at an early age (Handayani et al., 2017).

\section{The Effect of a History of Exclusive Breastfeeding on Children's Develop- ment}

The results of this study indicate that there is an effect between the history of exclusive 
breastfeeding on children's development and is statistically significant. The results of the analysis note that toddlers with incomplete exclusive breastfeeding history are more at risk of developing developmental disorders. Breastfeeding has also been linked to improved health outcomes in childhood, including improvements in children's neurocognitive development and lower rates of chronic diseases such as diabetes. The World Health Organization recommends giving babies 6 months of exclusive breastfeeding to receive maximum health benefits (Heymann et al., 2017).

Other studies have shown that breastfeeding can protect children from various diseases such as otitis media, malocclusion, dental caries, obesity and type 2 diabetes (Horta et al., 2015) and have been consistently associated with increased cognitive development in a child (Horta et al., 2015; Pérez et al., 2016).

This is the same as a study conducted by Boucher et al. (2017) which stated that recent study has supported a correlation between duration of breastfeeding and children's cognition beyond parental and socioenvironmental factors.

The results of several studies show a positive correlation between breastfeeding and children's neurological development and show that a longer duration of breastfeeding is beneficial for children's psychomotor development (Stelmach et al., 2019).

The same thing is shown in a study conducted by Victora et al. (2016). The nutritional benefits of breastfeeding and its protection against infection are well known. The findings from epidemiological and biological studies reinforce the fact that the decision not to breastfeed a child has a large longterm effect on children's health, nutrition, and development.

According to Grace et al. (2016) giving exclusive breastfeeding for 6 full months has been linked to some positive development outcomes including optimal neurodevelopment and early brain development, increased immunity, mental health, language skills, cognitive function, and academic achievement.

\section{The Effect of Number of Children on Children's Development}

The results of this study indicate that there is an effect between the number of children in an exclusive breastfeeding family on child development and is statistically significant. The results of the analysis note that toddlers who live with the number of children in families that are not ideal are more at risk of developing developmental disorders.

'Homeschooling' as a term of character learning at home, represents the impact of family education on children. On the other hand, the family as an institution must create conditions for the development of a positive correlation to work, which is thus a tendency towards the establishment of a better realistic approach to the development of children's better personalities (Ceka and Murati, 2016).

According to Listyaningsih. (2015) the ideal number of children in a family is 2 children. With the ideal number of children, the mother can focus more on taking care of her child and the sibling can play a role as a friend of interaction so that your presence is needed for the child to hone the ability to interact and develop (Sang and Nelson, 2017).

A previous study has shown similar results that a comfortable and safe home environment plays an important role in the development process of a child. Uncomfortable environments and the many conflicts that exist in a home can cause children's development is not optimal. A large number of children in a family can trigger frequent conflicts that will occur between siblings. Conflicts that occur within a family will be able to have 
a negative impact on the child's social-emotional development (Lucas and George, 2017).

The number of children who are less than ideal can also affect the closeness or bonding of a child with parents, especially mothers. The need for love will affect the child's social-emotional development which will have an impact on the child's social interaction in his environment (Steenbakkers et al., 2018).

\section{The Contextual Effect of Preschool on Child's Development}

The results of this study indicate that there is a contextual effect on the level of early childhood education on child development. The value of the effect of early childhood education at the second level is indicated by the ICC value of $9.4 \%$.

This is supported by a similar study which stated that the duration of teaching early childhood education or early education is positively affected by children's cognitive development and has a maximum effect on children aged 31 months or more. Whereas language development and literacy will maximally develop in children aged 19-31 months (Rao et al., 2019).

The demand for high-quality early childhood education, demonstrating the importance of the social, emotional, and cognitive development of early childhood has resulted in increased interest from educators, researchers, program designers, and the government in the provision of early childhood education led by effective educators. This intervention was carried out to support children's social and emotional growth. Therefore, this proves that the level of early childhood education can affect a child's development (O'Connor et al., 2018).

\section{AUTHOR CONTRIBUTION}

Ajeng Ayu Titah was the main researcher who also the study organizer. She collected the data, formulated articles of the study, and processed data. Prof. Harsono Salimo had a role in the background and discussion of the study. Dr. Eti Poncorini Pamungkasari had a role in the formulation of a framework of thinking and analyzing the data of the study.

CONFLICT OF INTEREST

There is no conflict of interest in this study.

FUNDING AND SPONSORSHIP

The source of funds in this study used personal funds from the main researcher.

ACKNOWLEDGEMENT

The researchers would like to express their gratitude to the Principal of Preschool in Wonokromo District, who had allowed this study to be carried out. The researchers also would like to say thank you to respondents who have been willing and cooperative to be the subject of this study.

\section{REFERENCE}

Black MM, Walker SP, Fernald LC, Andersen CT, DiGirolamo AM, Lu C, McCoy DC, et al. (2017). Early childhood development coming of age: science through the life course. The Lancet, 389(10064): 77-90. http://doi.org/10.1016/So1406736(16)31389-7.

Boucher O, Julvez J, Guxens M, Arranz E, Ibarluzea J, Sánchez De Miguel M, Sunyer J (2017). Association between breastfeeding duration and cognitive development, autistic traits and ADHD symptoms: A multicenter study in Spain. Pediatr Res. 81(3): 434-442. https://doi.org/10.1038/pr.2016.238.

Retrieved from 14/04/20.

Blumenfeld A, José C, Sabrina ID, Natalia S G, Yael S, Sandra G, Macario, Graciela $S$ (2018). Language development delay in 24-month-old children at a health care center of the City of Buenos Aires. 
Pujangkara et al./ Contextual Effect of Preschool on Children under Five's

Arch Argent Pediatr. 116(4). http://dx.doi.org/10.5546/aap.2018.eng.242.

Ceka A, Murati R (2016). The role of parents in the education of children. JEP. 7(5): 61-64. Retrieved from https://eric.ed.gov/?id=EJ1092391.

Cui Y, Liu H, Zhao L (2019). Mother's education and child development: evidence from the compulsory school reform in china. J Comp Econ, 47(3): 669-692. https://doi.org/10.1016/j.jce.2019.04.001.

Cyr D(2016). Nutrition and Child Development. Human Services Capstones. Paper 6. Retrieved from https://pdfs.semanticscholar.org/9f81/f1fd85d662135ob8c5692ddb4cbdf7db83b9.pdf.

Dinkes Jawa Timur (2018). Hasil Utama Riset Kesehatan Dasar Jawa Timur 2018. Jakarta: Badan Penelitian Dan Pengembangan Kesehatan, Kementerian Kesehatan Republik Indonesia.

Farooq MU, Rafique MZ, Shah MAR (2019). The effects of mother education and intervening mechanisms on ruralurban child stunting: evidence from Pakistan. Revista Pan-Amazônica de Saúde, 10. doi: 10.5123/S2176-6223201900044.

Fernald LC, Prado E, Kariger P, Raikes A (2017). A toolkit for measuring early childhood development in low and middle-income countries. International Bank for Reconstruction and Development. Retrieved from http://repositorio.minedu.gob.pe/handle/MINEDU/5723.

Grace T, Oddy W, Bulsara M, Hands B (2017). Breastfeeding and motor development: a longitudinal cohort study. Hum Mov Sci. 51: 9-16. http://dx.doi.org/10.1016/j.humov.2016.10.001.

Handayani DS, Sulastri A, Mariha T, Nurhaeni $N$ (2017). Penyimpangan tumbuh kembang anak dengan orang tua beker- ja. Jurnal Keperawatan Indonesia, 20(1): 48-55. http://doi.org/10.7454/jki.v20i1.439.

Hardilla DS, Salimo H, Pamungkasari EP (2020). Do early childhood schools have a contextual effect on child development aged 3-6 years in Tanjung Jabung Timur, Jambi?. J Matern Child Health, 5(2): 120-128. https://doi.org/10.26911/thejmch.2020.05.02.01.

Heymann J, Sprague AR, Nandi A, Earle A, Batra P, Schickedanz A, Chung PJ, Raub A (2017). Paid parental leave and family wellbeing in the sustainable development era. Public Health Rev, 38(1): 21. Doi: 10.1186/s40985-0170067-2.

Horta BL, Loret de Mola C, Victora CG (2015a). Longterm consequences of breastfeeding on cholesterol, obesity, systolic blood pressure and type 2 diabetes: a systematic review and metaanalysis. Acta Paediatr Int J Paediatr. Supplementum 104(467): 30-7. Doi: 10.1111/apa.13133.

Horta BL, Loret de Mola C, Victora CG. (2015b). Breastfeeding and intelligence: a systematic review and meta-analysis. Acta Paediatr Int J Paediatr. Supplementum 104 (467): 14-9. Doi: 10.1111/apa.13139.

Indriyani E, Dewi YLR, Salimo H (2018). Biopsychosocial determinants of stunting in children under five: a path analysis evidence from the border area West Kalimantan. J Matern Child Health. 3(2):146-155. http://doi.org/1026911.thejmch.2018.03.02.17.

Jensen SK, Tofail F, Haque R, Petri Jr WA, Nelson III C A (2019). Child development in the context of biological and psychosocial hazards among poor families in bangladesh. PloS one, 14(5). https://doi.org/10.1371/journal.pone.0215304 . 
Jeong J, McCoy DC, Fink G (2017). Pathways between paternal and maternal education, caregivers' support for learning, and early child development in 44 lowand middle-income countries. Early Child Res Q, 41: 136-148. http://dx.doi.org/10.1016/j.ecresq.2017.07.001.

Keats A (2018). Women's schooling, fertility, and child health outcomes: evidence from uganda's free primary education program. Journal of Development Economics, 135: 142-159. DOI: 10.1016/j.jdeveco.2018.07.002.

Khalil IAM, Troeger C, Rao P, Forouzanfar M, Columbara D, Misra K, Mokdad A (2016). Assessing the nonfatal burden of childhood diarrhea including malnutrition, physical growth, and cognitive development. In open forum infectious diseases 3(1220). Oxford University Press. https://doi.org/10.1093/-ofid/ofw172.923.

Kusumasari RA, Tamtomo D, Dewi YLR (2016). The relationship between parental socio-economic status, birthweight and development in children aged 1-5 years in Surakarta. J Matern Child Health. 1(13):195-199. http://doi.org/10.26911/thejmch.2016.01.03.07.

Krämer M (2017). Nutrition and child development in low-and middle-income countries-evaluation of three micronutrient interventions (Doctoral dissertation, Georg-August-Universität Göttingen). Retrieved from https://d-nb.info/1136785-191/34.

Lambregts-Rommelse N, Hebebrand $J$ (2017). Editorial focused issue the role of nutrition in child and adolescent onset mental disorders. Eur Child Adolesc Psychiatry. 26: 1007-1010. https://doi.org/10.1007/s00787-017-1041-8.

Listyaningsih U, Sumini S (2015). Jumlah anak ideal menurut remaja di Daerah
Istimewa Yogyakarta. Populasi. 23(2): 38-54. https://doi.org/10.22146/jp.15694.

Lucas TRG, George MW (2017). Are there individual and sibling differences in appraisals of interparental conflict?. J Fam Psychol. 31(7): 933. https://psycnet.apa.org/doi/10.1037/famoooo326.

Lolita, Dewi YLR, Murti B (2019). Multilevel analysis on the contextual effect of the integrated health post activity on development of children under five in Kubu Raya West Kalimantan. J Matern Child Health. 4(4): 222-229. http://doi.org/10.26911/thejmch.2019.04.04.01.

Mokomane M, Kasvosve I, Melo ED, Pernica JM, Goldfarb DM (2018). The global problem of childhood diarrhoeal diseases: emerging strategies in prevention and management. Ther Adv Infectious Dis. 5(1): 29-43. https://doi.org/10.1177/2049936117744429.

Onis, MD (2017). Nutrition and Health in a Developing World. Nutr Health. Https://doi.org/10.1007/978-3-319-43739-2.

O'Connor A, Blewitt C, Nolan A, Skouteris H (2018). Using intervention mapping for child development and wellbeing programs in early childhood education and care settings. Eval Program Plann. 68: 57-63. https://doi.org/10.1016/j.evalprogplan.2018.02.01.

Pace A, Luo R, Hirsh-Pasek K, Golinkoff R M (2017). Identifying pathways between socioeconomic status and language development. Annu Rev Linguist. 3: 285308. https://doi.org/10.1146/annurevlinguistics-011516-034226.

Pinkerton R, Reinaldo B Oriá, Aldo AM Lima, Elizabeth T, Rowagski, Mônica O B, Oriá Peter D, et al (2016). Early childhood diarrhea predicts cognitive delays in later childhood independently of malnutrition. Am. J. Trop. Med. Hyg, 
Pujangkara et al./ Contextual Effect of Preschool on Children under Five's

95(5). http://doi.10.4269/ajtmh.16-0150.

Piper JD, Chandna J, Allen E, Linkman K, Cumming O, Prendergast AJ, Gladstone MJ (2017). Water, sanitation and hygiene (wash) interventions: effects on child development in low-and middle-income countries. Cochrane Database Syst Rev. (3). http://doi.org/ 10.1002/14651858.CDo12613.

Pérez Escamilla R, Martinez JL, Segura Pérez $S$ (2016). Impact of the baby-friendly hospital initiative on breastfeeding and child health outcomes: a systematic review. Matern Child Nutr. 12(3): 402417. https://doi.org/10.1111/mcn.12294.

Profil Kesehatan Anak (2018). Profil Anak Indonesia. Jakarta: Kementerian Pemberdayaan Perempuan dan Perlindungan Anak.

Rao N, Richards B, Sun J, Weber A, Sincovich A (2019). Early childhood education and child development in four countries in East Asia and the pacific. Early Child Res Q, 47: 169-181. https://doi.org/10.1016/j.ecresq.2018.08.o 11.

Sang SA, Nelson JA (2017). The effect of siblings on children's social skills and perspective taking. Infant Child Dev, 26(6): 2023. https://doi.org/10.1002/icd.2023.

Slemming W, Kagura J, Saloojee H, Richter LM (2017). Early life risk exposure and stunting in urban South African 2-year old children. J Dev Orig Health Dis, 8(3): 301-310. https://doi.org/10.1017/S2040174417000034.

Stelmach I, Kwarta P, Jerzyńska J, Stelmach W, Krakowiak J, Karbownik M, Podlecka D, et al (2019). Duration of breastfeeding and psychomotor development in 1-year-old children-polish mother and child cohort study. Int $\mathrm{J}$ Occup
Med Environ Health. 32(2):175 - 184. https://doi.org/10.13075/ijomeh.1896.01328.

Steenbakkers A, Van Der Steen S, Grietens H (2018). The needs of foster children and how to satisfy them: A systematic review of the literature. Clin Child Fam Psychol Rev, 21(1): 1-12. https://doi.org/10.1007/s10567-017-0246-1.

Suryana, Fitri Y, Fajri K, Rahmad (2019). Pengaruh riwayat pemberian asi dan mp-asi terhadap pertumbuhan dan perkembangan anak (usia 12-24 bulan) di Kecamatan Kuta Alam Kota Banda Aceh. SEL Jurnal Penelitian Kesehatan. 6(1). 25-34. https://doi.org/10.22435/sel.v6i1.1723.

Ulfah E, Rahayuningsih, Herman H, Susiarno H, Gurnida, Gamayani U, Sukandar $\mathrm{H}$ (2018). Asuhan nutrisi dan stimulasi dengan status pertumbuhan dan perkembangan balita usia 12-36 bulan. Global Medical and Health Communication. 6(1): 12-20. http://dx.doi.org/10.29313/gmhc.v6i1.2323.

Urke HB, Contreras M, Matanda D J. (2018). The influence of maternal and household resources, and parental psychosocial child stimulation on early childhood development: a cross-sectional study of children 36-59 months in Honduras. Int. J. Environ. Res. Public Health. 15(5): 926. https://doi.org/10.3390/ijerph15050926.

Victora CG, Bahl R, Barros AJ, França GV, Horton S, Krasevec J, Murch S, Sankar MJ, Walker N, Rollins NC, Group TLB $S$ (2016). Breastfeeding in the 21st century: epidemiology, mechanisms, and lifelong effect. The Lancet, 387(10017): 475-490. https://doi.org/10.1016/So1406736(15)01024-7. Retrieved from 11/04/20.

Vikram K, Chen F, Desai S (2018). Mothers' work patterns and Children's cognitive 
Pujangkara et al./ Contextual Effect of Preschool on Children under Five's

achievement: Evidence from the India Human Development survey. Soc Sci Res, 72: 207-224. https://doi.org/10$.1016 /$ j.ssresearch.2018.02.003.

Wati DE (2017). Pengetahuan Guru PAUD Tentang KPSP (Kuesioner Pra Skrining Perkembangan) sebagai Alat Deteksi Tumbuh Kembang Anak. Jurnal VARIDIKA, 28(2): 133-139. https://doi.org/10.23917/varidika.v28i2.3028.

Wijayanti A, Wekadiguna CSP, Murti B (2018). The effect of parenting style, billingual school, social environment, on speech and language development in preschool children in Surakarta, Central Java. J Matern Child Health. 3(3). https://doi.org/10.26911/thejmch.2018.03.03.03.

Yadika ADN, Berawi KN, Nasution SH (2019). Pengaruh stunting terhadap perkembangan kognitif dan prestasi belacuijar. Jurnal Majority, 8(2): 273-282. 